\title{
Multivariate analysis of the behavior and physiology of Girolando heifers in pasture
}

\author{
Pedro H. D. Batista ${ }^{1}$, Gledson L. P. de Almeida ${ }^{1}$, Héliton Pandorfi ${ }^{1}$, Airon A. S. de Melo ${ }^{2}$, \\ Alex S. Moraes ${ }^{3} \&$ Cristiane Guiselini ${ }^{1}$
}

${ }^{1}$ Universidade Federal Rural de Pernambuco/Departamento de Engenharia Agrícola/Programa de Pós-Graduação em Engenharia Agrícola. Recife, PE,
Brasil. E-mail: giga_pedro@hotmail.com (Corresponding author) - ORCID: 0000-0002-8710-5678; gledson.almeida@ufrpe.com.br - ORCID: 0000-
0002-5813-4517; hpandorf@hotmail.com - ORCID: 0000-0002-2037-8639; cguiseli@hotmail.com - ORCID: 0000-0003-2909-9502
${ }^{2}$ Universidade Federal Rural de Pernambuco/Departamento de Ciência Animal. Garanhuns, PE, Brasil. E-mail: airon.melo@ufrpe.br - ORCID: 0000-
0001-7527-1081
${ }^{3}$ Universidade Federal Rural de Pernambuco/Departamento de Química. Recife, PE, Brasil. E-mail: alex.moraes@ufrpe.br - ORCID: 0000-0002-7448-5683

\begin{abstract}
The objective of this study was to evaluate the thermal effect on the behavioral and physiological changes of Girolando heifers by means of principal components analysis. The research was conducted in the Agreste region of the state of Pernambuco, Brazil. Three heifers submitted to the continuous grazing system were used. For the determination of the thermal effect on the animals, the variables dry bulb temperature and relative air humidity were recorded, which allowed to determine the temperature and humidity index and the specific enthalpy. The physiological variables monitored were the respiratory rate, rectal temperature and skin temperature. The quantified behavioral indicators were walking, drinking, eating, ruminating and leisure, to determine the percentage of time spent in each behavior. The variables of the study were submitted to exploratory and descriptive analysis, in order to infer the degree of association of the main components. The multivariate analysis allowed to establish the degree of pertinence between the physiological signs and behavioral patterns associated with the thermal environment, which indicated heifers adaptation to continuous grazing, even in critical meteorological conditions.
\end{abstract}

Key words: principal components, animal thermal comfort, animal adaptability

\section{Análise multivariada do comportamento e fisiologia de novilhas girolando a pasto}

RESUMO: Objetivou-se avaliar o efeito térmico na mudança comportamental e fisiológica de novilhas girolando, por meio da análise de componentes principais. A pesquisa foi conduzida na região Agreste do estado de Pernambuco, Brasil. Foram utilizadas três novilhas submetidas ao sistema de pastejo contínuo. Para determinação do efeito térmico sobre os animais, foram registradas as variáveis temperatura de bulbo seco e umidade relativa do ar, o que permitiu determinar o índice de temperatura e umidade e a entalpia específica. As variáveis fisiológicas monitoradas foram a frequência respiratória, temperatura retal e temperatura de pelame. Os indicadores comportamentais quantificados foram andando, bebendo, comendo, ruminando e ócio, para determinação da porcentagem de tempo despendido em cada comportamento. As variáveis do estudo foram submetidas a análise exploratória e descritiva, para inferência do grau de associação dos componentes principais. A análise multivariada permitiu estabelecer o grau de pertinência entre os sinais fisiológicos e padrões comportamentais associado ao ambiente térmico, que indicaram adaptação das novilhas ao pastejo contínuo, mesmo em condições meteorológicas críticas.

Palavras-chave: componentes principais, conforto térmico animal, adaptabilidade animal 


\section{INTRODUCTION}

The action of meteorological elements may interfere with animal behavior, physiological responses and production, attributed to the need for adaptation and transfer of energy from production to maintenance, causing impact on the zootechnical indices and economic losses, especially in the semi-arid region, where high temperatures impose greater challenge to the thermal balance of the animals.

Given this scenario, livestock farming is the preponderant activity in the region, but penalized by the thermal stress faced by dairy cattle (Daltro et al., 2017). Thus, two strategies can be used to ensure animal performance; the first one would be the use of less demanding races, genetically more adapted to the climate of the region, and the second one would be the modification of the production environment, in order to reduce thermal stress and facilitate homeothermy (Almeida et al., 2013).

In hot periods, with records of high ambient temperature and low wind speed, cattle change their behavioral patterns, with reduction in eating and ruminating times and increase in leisure time, a probable attempt to reduce the production of metabolic heat. In addition to the reduction in the eating activity, there is an inversion of food habits, in which the animals avoid grazing during the hottest times and increase night grazing by 6 h $30 \mathrm{~min}$ (Geron et al., 2014).

With emphasis on the criteria of thermal evaluation and behavioral responses, the use of multivariate analysis to determine the degree of association of the principal components allows to simultaneously explore various correlated experimental factors (Massari et al., 2015). The utilization of the technique in studies on dairy cattle raising environment includes research on the evaluation of heat tolerance (Daltro et al., 2017) and impacts on milk production due to meteorological variables (Gabbi et al., 2017).

Thus, the present study aimed to evaluate the thermal effect on the behavioral and physiological changes of Girolando heifers through principal component analysis.

\section{Material ANd Methods}

The study was conducted in a commercial dairy cattle farm, Roçadinho Farm, located in the municipality of Capoeiras, Agreste Mesoregion and Vale do Ipojuca Microregion, Pernambuco, Brazil ( $8^{\circ} 36^{\prime} \mathrm{S}, 36^{\circ} 37^{\prime} \mathrm{W}$ and altitude of $850 \mathrm{~m}$ ). The climate of the region is characterized as semi-arid (Bsh), according to Köppen's classification, with mean annual rainfall of $588 \mathrm{~mm}$ (Almeida et al., 2011).

The study was conducted in an area under Brachiaria decumbens pasture from October 16 to November 11, 2016, totaling 21 days of monitoring, in a $40 \times 40 \mathrm{~m}$ plot, with an attached resting area of $8 \times 10 \mathrm{~m}$, with drinking fountain and shading net $(80 \%)$, which provided a $15 \mathrm{~m}^{2}$ area of artificial shading.

Three Girolando heifers were used, with 7/8 Holstein-Gir genetic composition, mean weight of $300 \mathrm{~kg}$, managed in continuous grazing system. Forage had mean initial height of $0.90 \mathrm{~m}$, and grazing was suspended when it reached $0.20 \mathrm{~m}$, in a total of 21 days.
The meteorological variables, dry bulb temperature $\left(\mathrm{T}_{\mathrm{db}}\right.$, ${ }^{\circ} \mathrm{C}$ ) and relative air humidity $(\mathrm{RH}, \%)$ were recorded every ten minutes, in the resting area and in meteorological shelter, by a Hobo U12-12 datalogger (Onset Computer Corporation Bourne, MA, USA). The sensors were fixed inside the meteorological shelter installed beside the grazing area, at $1.50 \mathrm{~m}$ height from the soil, and under shading net, located in the resting area.

Wind speed $\left(\mathrm{m} \mathrm{s}^{-1}\right)$ was recorded twice a week, on days that coincided with the evaluation of physiological records, every hour from 6 to $18 \mathrm{~h}$, using a propeller anemometer of the brand AZ Instrument ${ }^{\oplus}$, model 8908.

The thermal characterization of the environment was carried out using the Temperature Humidity Index (THI), Eq. 1, proposed by Thom (1959), and the specific enthalpy (h, kJ kg-1 of dry air) suggested by Rodrigues et al. (2011), according to Eq. 2.

$$
\mathrm{THI}=\mathrm{T}_{\mathrm{db}}+0.36 \mathrm{~T}_{\mathrm{dp}}+41.5
$$

where:

$\mathrm{T}_{\mathrm{db}}$ - dry bulb temperature, ${ }^{\circ} \mathrm{C}$; and,

$\mathrm{T}_{\mathrm{dp}}$ - dew point temperature, ${ }^{\circ} \mathrm{C}$.

$$
\mathrm{h}=1.006 \mathrm{~T}_{\mathrm{db}}+\frac{\mathrm{RH}}{\mathrm{P}_{\mathrm{atm}}} 10^{\left(\frac{7.5 \mathrm{~T}_{\mathrm{db}}}{237.3+\mathrm{T}_{\mathrm{db}}}\right)}\left(71.28+0.052 \mathrm{~T}_{\mathrm{db}}\right)
$$

where:

$\mathrm{T}_{\mathrm{db}}$ - dry bulb temperature, ${ }^{\circ} \mathrm{C}$;

$\mathrm{RH}$ - relative humidity, \%; and,

$\mathrm{P}_{\mathrm{atm}}$ - local atmospheric pressure, $\mathrm{mmHg}$.

The physiological responses of the animals were evaluated by recording rectal temperature $\left(\mathrm{RT} ;{ }^{\circ} \mathrm{C}\right)$, respiratory rate (RR; mov $\mathrm{min}^{-1}$ ) and skin temperature (ST; $\left.{ }^{\circ} \mathrm{C}\right)$, from 6 to 18 $\mathrm{h}$, at $3 \mathrm{~h}$ interval, during two days per week along the study. RR was checked by counting the number of movements of the flank region, within an interval of $1 \mathrm{~min}$. After recording RR, RT readings were taken using a digital veterinary thermometer with scale from 20 to $50^{\circ} \mathrm{C}$, inserted into the rectum of the animals for $1 \mathrm{~min}$, for stabilization, and measurement of temperature.

Skin temperature was obtained from thermal images, recorded using a thermographic camera, model FLIR i60, to determine the average surface temperature of the animals, delimited by an area which encompassed the region of thorax and abdomen. The images were recorded on the right side of the animals, at a $2.50 \mathrm{~m}$ distance, and corrected by the software FLIR QuickReport, considering emissivity of 0.98 and the thermo-hygrometric variables at the moment of obtaining the images.

The behavior of the animals was recorded by a video camera equipped with infrared LED lights, to assist in nighttime monitoring, positioned in such a way that the visual field included all the grazing area, actuated on days which did not coincide with the recording of physiological variables, once a week.

Behavioral quantification (walking, drinking, eating, ruminating and leisure) was based on an ethogram developed 
by Almeida et al. (2013), adapted from the instantaneous scanning method (Altmann, 1974), in which the video was paused every $10 \mathrm{~min}$, recording the behavior observed at that moment, along $24 \mathrm{~h}$.

Behavioral variables were subjected to analysis of distribution of the percentage of time spent, assessed by chisquare and probability tests, subdivided into $3 \mathrm{~h}$ intervals, using the program SAS Institute Inc. (2016).

Meteorological ( $\mathrm{T}_{\mathrm{db}}$ and $\mathrm{RH}$ ), physiological (RT, RR and $\mathrm{ST}$ ), behavioral (walking, drinking, eating, ruminating and leisure) variables and the comfort indices (THI and h) were subjected to multivariate principal component analysis, divided into two steps; the first one contained behavioral variables, meteorological variables and comfort indices, and the second one was composed of the meteorological responses, physiological responses and comfort indices. Principal component analysis allowed to investigate the interactions between the variables in study, in order to provide a reduction in the dimensionality and project the parameters which best explain the adaptability of the heifers (7/8 Holstein-Gir) to the hourly intervals established along the day.

\section{Results AND Discussion}

The highest mean value of dry bulb temperature $\left(\mathrm{T}_{\mathrm{db}}\right)$ occurred at $14 \mathrm{~h}$, and relative air humidity $(\mathrm{RH})$ showed variation inversely proportional to $\mathrm{T}_{\mathrm{db}}$ during all the studied period (Figure 1).

For cattle, the best thermal conditions are found between 10 and $27{ }^{\circ} \mathrm{C}$, with relative air humidity of 60 to $70 \%$ and wind speed of 1.4 to $2.2 \mathrm{~m} \mathrm{~s}^{-1}$ (Baêta \& Souza, 2010), which facilitate the processes of thermal energy transfer through sensitive media.

However, the conjuncture suggested by Baêta \& Souza (2010) was to dry bulb temperature overcome in the studied environment, in both pasture and shade, within the interval from 11 to $17 \mathrm{~h}$ (Figure 1). These findings corroborate Barnabé et al. (2015), who found mean air temperature of the order of $32^{\circ} \mathrm{C}$, between 11 and $16 \mathrm{~h}$, in the Agreste region of Pernambuco, in a study on housing adequacy for Girolando calves.

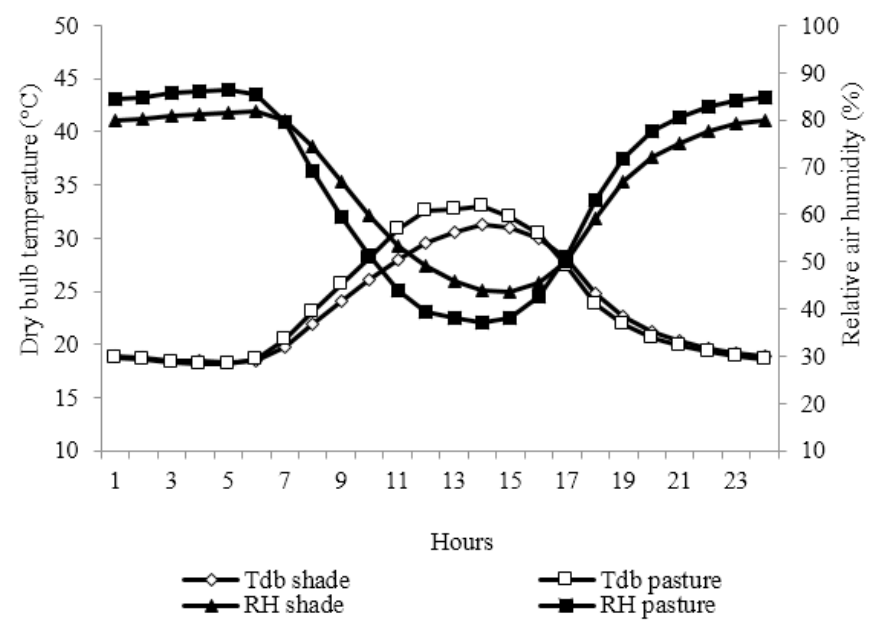

Figure 1. Mean hourly variation of dry bulb temperature (Tdb, ${ }^{\circ} \mathrm{C}$ ) and relative air humidity ( $\left.\mathrm{RH}, \%\right)$ in the pasture and in the shade
The values of the temperature-humidity index (THI) in the pasture and in the shade were higher from 12 to $15 \mathrm{~h}$, with mean of 79.8 in the pasture and 78.5 in the shade, i.e., the THI was $1.6 \%$ inferior in the shade (Figure 2), classified as moderate (79 to 88) according to Armstrong (1994). Passini et al. (2014), testing heat tolerance in Girolando cattle, obtained maximum THI of 78.8 at $13 \mathrm{~h}$ and, at this time, the $\mathrm{T}_{\mathrm{db}}$ reached a value of about $31^{\circ} \mathrm{C}$.

Thus, it is assumed that under the studied condition, the animals experienced micrometeorological conditions that exposed the heifers to the upper critical limit for THI, but without expressive effect on the production, since it still allowed satisfactory physiological and behavioral adjustments for the maintenance of homeothermy (Armstrong, 1994).

The mean hourly variation of enthalpy $(h)$ for pasture and shade caused a condition of discomfort for the animals between 10 and $16 \mathrm{~h}$, considering the critical limit established by Almeida et al. (2011), equal to $67.4 \mathrm{~kJ} \mathrm{~kg}^{-1}$ (Figure 2). Tavares et al. (2016) observed animal discomfort conditions at sites with high wind speed and very low enthalpy, such as a characteristic of cold stress, and in environments with high enthalpy and low wind speed, as a characteristic of heat stress. In the same study, the authors established the bioclimatic zoning for Brazil and classified the Pernambuco state as thermal discomfort zone for cattle.

Respiratory rate $(\mathrm{RR})$ values considered as adequate are between 18 and 60 mov min $^{-1}$ (Hahn et al., 1997). Therefore, the results point to a RR considered as normal along the studied period (Table 1), which indicates adaptation of the animals to the challenge imposed by the production environment. Similar results of RR were obtained by Almeida et al. (2011) and Barros Junior et al. (2016) for Girolando cattle in the semi-arid regions of Pernambuco and Piauí, respectively.

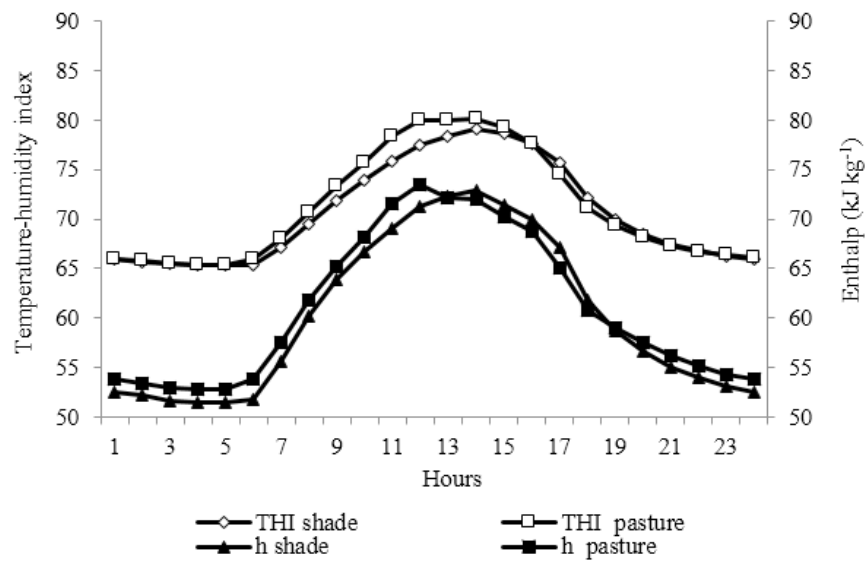

Figure 2. Mean hourly variation of Temperature Humidity Index (THI) and specific enthalpy ( $\mathrm{h}, \mathrm{kJ} \mathrm{kg}^{-1}$ of dry air) in the pasture and in the shade

Table 1. Descriptive statistical values of the physiological variables respiratory rate $\left(\mathrm{RR}, \mathrm{mov}^{\mathrm{min}}{ }^{-1}\right)$, rectal temperature $\left(\mathrm{RT},{ }^{\circ} \mathrm{C}\right)$ and skin temperature $\left(\mathrm{ST},{ }^{\circ} \mathrm{C}\right)$ of the animals

\begin{tabular}{ccccccr}
\hline Variables & Min & Max & Mean & Median & SD & \multicolumn{1}{c}{ CV } \\
RR & 22.00 & 43.00 & 32.53 & 33.00 & 5.59 & 17.19 \\
RT & 36.10 & 39.70 & 38.27 & 38.35 & 0.60 & 1.57 \\
ST & 25.60 & 48.40 & 31.39 & 30.55 & 4.46 & 14.20 \\
\hline
\end{tabular}

MIN - Minimum; MAX - Maximum; SD - Standard deviation; CV (\%) - Coefficient of variation 
It can be noted in Table 1 that the rectal temperature (RT) of the animals remained within normal physiological values, which range from 38 to $39^{\circ} \mathrm{C}$ (Du Preez, 2000). According to Pinheiro et al. (2015), RR and RT values lower than or equal to $54 \mathrm{mov} \mathrm{min}^{-1}$ and $38.7{ }^{\circ} \mathrm{C}$, respectively, indicate thermal comfort state of the animals and adaptability to the climatic conditions of the region.

A study conducted by Barros Junior et al. (2016) points to variation in RR and RT in the morning and afternoon, with values of 38.35 and $38.68{ }^{\circ} \mathrm{C}$ for $\mathrm{RT}$ and of 34.07 and $34.37 \mathrm{mov} \mathrm{min}^{-1}$ for $\mathrm{RR}$, respectively.

These results corroborate those found in the present study, which demonstrate adaptive responses of Girolando cattle, through evaluation of the thermo-regulatory characteristics exhibited by the animals exposed to the semi-arid conditions.

It can be observed in Table 1 that the mean value of skin temperature (ST) was close to those found by Martello et al. (2016), 31.4 and $36.47^{\circ} \mathrm{C}$. However, the ST may be related to wind speed, which remained within the range considered as ideal for cattle, showing mean of $2.2 \mathrm{~m} \mathrm{~s}^{-1}$, and favored the efficiency of thermo-regulatory mechanisms.

Similar results were found by Moreira et al. (2017), who obtained mean ST of $30.51{ }^{\circ} \mathrm{C}$, observing the physiological responses and adaptability of $3 / 4$ Holstein $\mathrm{x}$ Zebu cows under semi-arid climate.

The physiological variables (RR, RT and ST) do not indicate a situation of thermal stress for the heifers (7/8 Holstein-Gir) in continuous grazing system, although the THI and h showed moderate to critical intensity, with duration of three and six hours, respectively. The adaptability indicators associated with energy transfer by convection between animals and the environment attenuated the effects of the stressing agents.

The behavioral activities developed were dependent on the hourly intervals evaluated (Table 2).

The heifers showed considerable frequency of grazing in the periods in which the comfort indices were high (Figure 2), from 12 to $15 \mathrm{~h}$, thus emphasizing the tolerance of the animals to the imposed environment conditions. However, the preferential grazing occurred at dusk, from 15 to $18 \mathrm{~h}(8.41 \%)$, interval in which the THI was classified as mild (72 to 78 ) according to Armstrong (1994).

Under optimal thermal conditions, the animals reduce the eating frequency at the hottest times of the day. In this case, the search for food is more intense in the first hours of the morning and in the late afternoon, when temperatures are still low; opposite behavior may mean adaptability of the animals to the environment (Zanine et al., 2008).
Similar results were found by Fonseca et al. (2014), evaluating the ingestive behavior of cows (Holstein x Gir) in Brachiaria decumbens pastures in the Piauí state, where the animals reduced the grazing activity and intensified rumination and leisure activities from $18 \mathrm{~h}$, as identified in the present study, showing values of about $8.72 \%$ (rumination) and $13.42 \%$ (leisure) of the time spent from 18 to $0 \mathrm{~h}$, respectively (Table 2).

Highest water intake by the animals occurred from 9 to $12 \mathrm{~h}(0.62 \%)$ and from 18 to $21 \mathrm{~h}(0.46 \%)$, thus indicating that the animals drank more water in periods of high THI and $h$, and after greater consumption of forage. Therefore, the results corroborate Sun et al. (2014), who reported that water intake is related to environmental temperature, air humidity, pasture moisture content, wind speed, solar radiation and dry matter intake.

According to Pazdiora et al. (2011), animals normally ruminate during the night and periods of rumination are also conditioned by food intake and climatic conditions. The rumination of the heifers in the present study was higher during the night period (13.35\%), in which the animals were stressed by heat according to the classification of THI and $h$. A rumination frequency $(6.48 \%)$ also occurred within the interval from 6 to $18 \mathrm{~h}$, corroborating Nascimento et al. (2013), who evaluated the ingestive behavior of mixed cows (Holstein/ Zebu), in the Agreste region of Paraíba.

Figures $3 \mathrm{~A}$ and $\mathrm{B}$ correspond to the principal component analysis, for the behavior of the animals in grazing associated with meteorological variables or comfort indices. It can be observed that, from the data collection point of view, the technique of principal components was satisfactory to explain a large percentage of this information, because it integrates the thermal comfort indices with the other variables studied, since they have different origins and dimensions.

The results indicate that a total of $65 \%$ of all the information of the system was explained by the first two principal components (PC1 and PC2), corroborating Massari et al. (2015), who used this statistical method for associations between animal thermal comfort and the variables observed in growing swine.

The behavioral variables walking, drinking and eating are grouped with the variables $\mathrm{T}_{\mathrm{db}}$, THI and $\mathrm{h}$ (Figures $3 \mathrm{~A}$ and $\mathrm{B}$ ), suggesting that the animals were doing these activities in the periods in which the temperature was higher ( 9 to $18 \mathrm{~h}$ ). Thus, it is possible to observe that the animals continued eating even with the increase of temperature, reflecting their adaptability to this region, as verified in the physiological analyses (Table 1).

Table 2. Percentage of time spent by the animals in each activity

\begin{tabular}{|c|c|c|c|c|c|c|}
\hline Intervals & Walking & Drinking & Eating & Ruminating & leisure & Total (\%) \\
\hline $0-3 \mathrm{~h}$ & 0.15 & 0.15 & 1.62 & 3.47 & 7.10 & 12.5 \\
\hline $3-6 \mathrm{~h}$ & 0 & 0.08 & 4.17 & 1.16 & 7.10 & 12.5 \\
\hline $6-9 \mathrm{~h}$ & 0.54 & 0.31 & 6.48 & 1.16 & 4.01 & 12.5 \\
\hline $9-12 \mathrm{~h}$ & 0 & 0.62 & 4.94 & 1.77 & 5.17 & 12.5 \\
\hline $12-15 \mathrm{~h}$ & 0.39 & 0.08 & 6.94 & 2.08 & 3.01 & 12.5 \\
\hline $15-18 \mathrm{~h}$ & 0.85 & 0.31 & 8.41 & 1.47 & 1.47 & 12.5 \\
\hline $18-21 \mathrm{~h}$ & 0.15 & 0.46 & 1.85 & 4.71 & 5.32 & 12.5 \\
\hline $21-0 \mathrm{~h}$ & 0 & 0 & 0.39 & 4.01 & 8.10 & 12.5 \\
\hline Total & 2.08 & 2.01 & 34.80 & 19.83 & 41.28 & 100 \\
\hline & 389.011 & & DF 28 & \multicolumn{3}{|c|}{ Probability 0.001} \\
\hline
\end{tabular}


A.

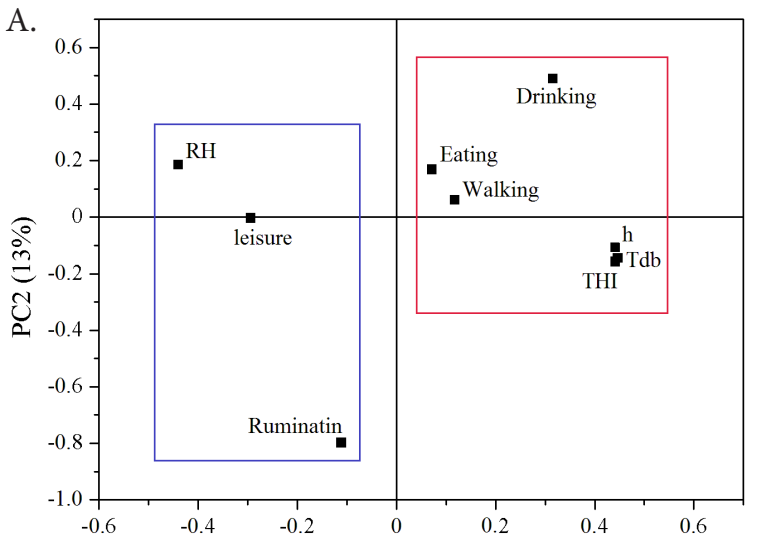

B.

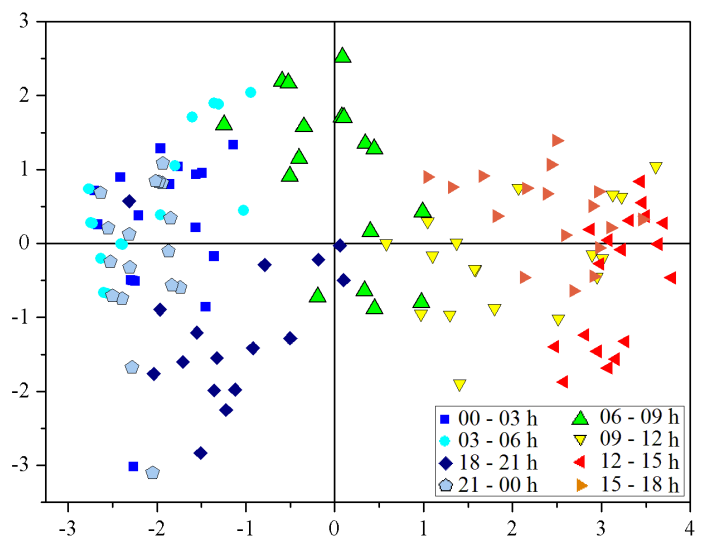

$\mathrm{PC} 1(52 \%)$

Figure 3. Principal component analysis of meteorological and behavioral variables: coefficients (A) and scores (B)
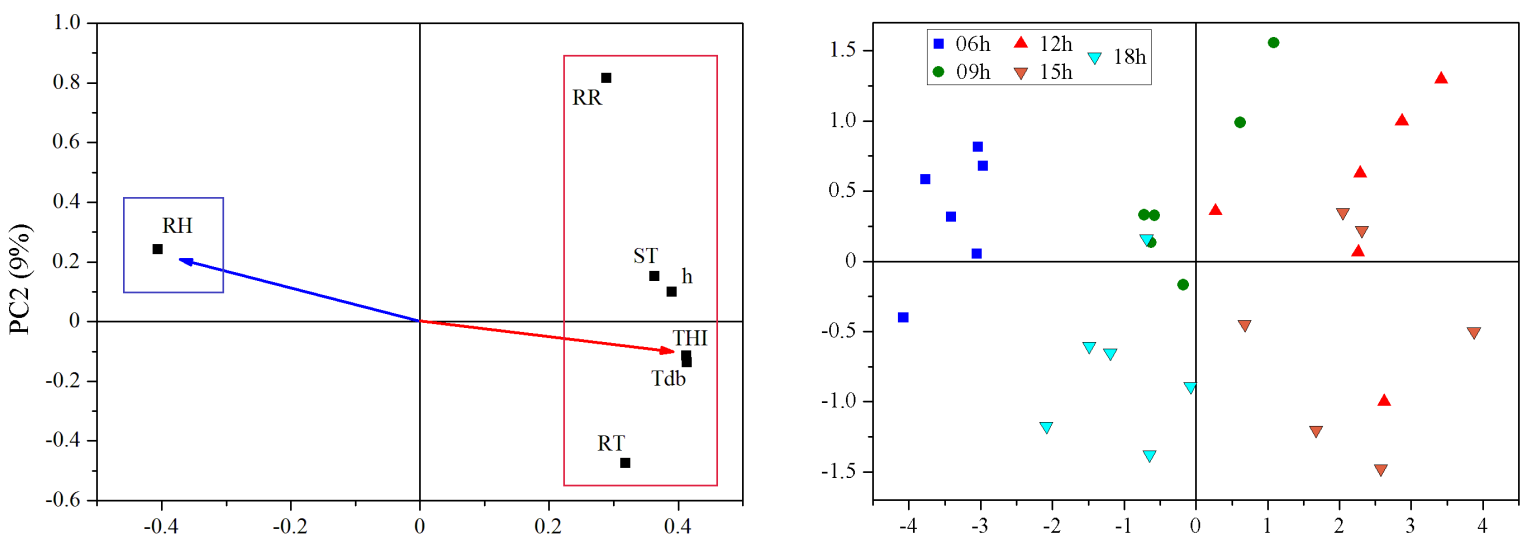

$\mathrm{PC} 1(76 \%)$

Figure 4. Principal component analysis of physiological and environmental variables: coefficients (A) and scores (B)

According to Zanine et al. (2008), animals tend to drastically reduce food intake when they are under thermal stress. It can be observed that in the period of lower temperatures ( 18 to $6 \mathrm{~h}$ ), the animals tended to remain in leisure and ruminating, and the highest RH values also occurred within this interval. In contrast, Massari et al. (2015), who used multivariate analysis to characterize the behavior of swine using wean-to-finish system, as a function of thermal comfort, observed that the animals tended to remain lying down with the increment of temperature.

In Figures $4 \mathrm{~A}$ and $\mathrm{B}$, it is possible to note that the total of information explained by the system was $85 \%$ in $\mathrm{PC} 1$ and $\mathrm{PC} 2$. As the physiological variables were grouped with $\mathrm{T}_{\mathrm{db}}$, THI and $\mathrm{h}$, there was an increase in the discomfort as the temperature had greater influence on the animals at 12 and $15 \mathrm{~h}$.

Thus, in the intervals of 6-9 and 18-21 h, which are times of mild temperatures (Figure 1), there was higher correlation with RH and also the lowest values of RT, RR and ST. This association was also found by Barbosa et al. (2014), who employed multivariate analysis to assess heat tolerance in cattle and observed that during the times of greater availability of solar radiation, and consequent increase of air temperature, the physiological variables of the animals tended to increase.

Daltro et al. (2017), using principal component analysis to examine the resistance to heat of dairy cows through infrared technology, found that in the periods in which the animals were under higher heat stress, there were more evident responses in the intensification of the physiological mechanisms of energy dissipation to the environment, in order to maintain homeothermy.

\section{Conclusions}

1. Principal component analysis allowed to establish the degree of pertinence between physiological signs and behavioral patterns associated with the thermal environment.

2. The behavioral responses indicate that the heifers were adapted to the continuous grazing system, even under critical meteorological conditions.

\section{ACKNOWLedgments}

We would like to thank the Fundação de Amparo à Ciência e Tecnologia do Estado de Pernambuco (FACEPE APQ-04655.03/14) for financial support for the development of this research and is Coordenação de Aperfeiçoamento de Pessoal de Nível Superior (CAPES, Brazil) for granting scholarships.

\section{Literature Cited}

Almeida, G. L. P. de; Pandorfi, H.; Barbosa, S. B. P.; Pereira, D. F.; Guiselini, C.; Almeida, G. A. P. de. Comportamento, produção e qualidade do leite de vacas Holandês-Gir com climatização no curral. Revista Brasileira de Engenharia Agrícola e Ambiental, v.17, p.892-899, 2013. http://dx.doi.org/10.1590/S1415-43662013000800014 
Almeida, G. L. P. de; Pandorfi, H.; Guiselini, C.; Henrique, H. M.; Almeida, G. A. P. de. Uso do sistema de resfriamento adiabático evaporativo no conforto térmico de vacas da raça girolando. Revista Brasileira de Engenharia Agrícola e Ambiental, v.15, p.754760, 2011. http://dx.doi.org/10.1590/S1415-43662011000700015

Altmann, J. Observational study of behavior:Sampling methods. Behaviour, v.49, p.227-267, 1974. https://doi.org/10.1163/156853974X00534

Armstrong, D. V. Heat stress interaction with shade and cooling. Journal of Dairy Science, v.77, p.2044-2050, 1994. https://doi.org/10.3168/ jds.S0022-0302(94)77149-6

Baêta, F. da C.; Souza, C. de F. Ambiência em edificações rurais: Conforto animal. 2.ed. Viçosa: Editora UFV, 2010. 269p.

Barbosa, B. R. P.; Santos, S. A.; Abreu, U. G. P. de; Egito, A. A.; Comastri Filho, J. A.; Juliano, R. S.; Paiva, S. R.; McManus, C. Heat tolerance in Nelore branco, Nelore vermelho and Pantaneira breeds in the Pantanal region, Brazil. Revista Brasileira de Saúde e Produção Animal, v.15, p.854-865, 2014. https://doi.org/10.1590/ S1519-99402014000400010

Barnabé, J. M. C.; Pandorfi, H.; Almeida, G. L. P. de; Guiselini, C.; Jacob, A. L. Thermal comfort and performance Holstein/Gir calves housed in individual shelters with different covers. Revista Brasileira de Engenharia Agrícola e Ambiental, v.19, p.481488, 2015. https://doi.org/10.1590/1807-1929/agriambi. v19n5p481-488

Barros Junior, C. P.; Sousa, P. H. A. A. de; Evangelista, A. F.; Cavalcante, D. H.; Barros, T. D.; Luz, C. S. M.; Fonseca, W. J. L.; Borges, L. da S.; Maia, F. S. P.; Carvalho, M. D. F.; Sousa Júnior, S. C. de. Seasonal and diurnal differences in the responses of Girolando cows to the thermal environment of Piauí, semiarid coast of Brazil. Journal of Animal Behaviour and Biometeorology, v.4, p.84-88, 2016.

Daltro, D. dos S.; Fischer, V.; Alfonzo, E. P. M.; Dalcin, V. C.; Stumpf, M. T.; Kolling, G. J.; Silva, M. V. G. B. da; McManus, C. Infrared thermography as a method for evaluating the heat tolerance in dairy cows. Revista Brasileira de Zootecnia, v.46, p.374-383, 2017. https://doi.org/10.1590/s1806-92902017000500002

Du Preez, J. H. Parameters for the determination and evaluation of heat stress in dairy cattle in South Africa. Onderstepoort Journal of Veterinary Research, v.67, p.263-271, 2000.

Fonseca, W. J. L.; Fonseca, W. L.; Sousa, P. H. A. A. de; Guerra, L. de O.; Luz, C. S. M.; Santos, T. R. dos; Vogado, G. M. S.; Borges, L. da S.; Almeida Júnior, T. F. de; Sousa Júnior, S. C. de. Ingestive behavior of cows in pastures Andropogon gayanus and Brachiaria decumbens in Southern State of Piauí, Brazil. Journal of Agricultural Science, v.6, p.144-150, 2014.

Gabbi, A. M.; Peripolli, V.; Cobuci, J. A.; Fischer, V.; Costa Junior, J. B. G.; McManus, C. Can meteorological variables affect milk production in different lactation orders of dairy cows in the Cfb climatic zone? A case study in Southern Brazil. Archivos de Zootecnia, v.66, p.271-278, 2017.

Geron, L. J. V.; Zeoula, L. M.; Yoshimura, E. H.; Franco, S. L.; Chiquitelli Neto, M.; Paula, E. M.; Samensari, R. B.; Peres, L. P. Ingestive behavior of Nellore heifers grazing receiving the supplement based on propolis or monensin. Semina: Ciências Agrárias, v.35, p.2047-2062, 2014. https://doi.org/10.5433/1679$0359.2014 \mathrm{v} 35 \mathrm{n} 4 \mathrm{p} 2047$
Hahn, G.; Parkhurst, A.; Gaughan, J. Cattle respiration rate as a function of ambient temperature. Transactions of the American Society of Agricultural Engineers, v.40, p.97-121, 1997.

Martello, L. S.; Silva, S. da L. e; Gomes, R. da C.; Corte, R. R. P. da S.; Leme, P. R. Infrared thermography as a tool to evaluate body surface temperature and its relationship with feed efficiency in Bos indicus cattle in tropical conditions. International Journal of Biometeorology, v.60, p.173-181, 2016. https://doi.org/10.1007/s00484-015-1015-9

Massari, J. M.; Curi, T. M. R. de C.; Moura, D. J. de; Medeiros, B. B. L.; Salgado, D. A. Behavioral characteristics of different gender division of growing and finishing swine in "wean to finish" system. Engenharia Agrícola, v.35, p.646-656, 2015. https://doi. org/10.1590/1809-4430-Eng.Agric.v35n4p646-656/2015

Moreira, S. J. M.; Carvalho, C. C. S.; Santos, L. V.; Ruas, J. R. M.; Andrade Júnior, I. O.; Aiura, A. L. O.; Gonçalves, G. A. M. Respostas fisiológicas e adaptabilidade de vacas $3 / 4$ holandês x zebu ao clima do semiárido. Boletim de Indústria Animal, v.74, p.162-168, 2017.

Nascimento, G. V. do; Cardoso, E. de. A.; Batista, N. L.; Souza, B. B. de; Cambuí, G. Ingestive behavior of crossbred cows (Holstein/Zebu) in rotational grazing on Brachiaria brizantha cv. Marandu. Journal of Animal Behaviour and Biometeorology, v.1, p.31-36, 2013.

Passini, R.; Barros, B. de C.; Macena, T. C. Heat tolerance index in bovine girolando crossbred in the center-west of Brazil. Acta Veterinaria Brasilica, v.8, p.163-168, 2014.

Pazdiora, R. D.; Brondani, I. L.; Silveira, M. F. da; Arboitte, M. Z.; Cattelam, J.; Paula, P. C. de. Effects of supply frequency of roughage and concentrate on ingestive behavior of feedlot cows and heifers. Revista Brasileira de Zootecnia, v.40, p.2244-2251, 2011. https://doi.org/10.1590/S1516-35982011001000026

Pinheiro, C. A. de; Saraiva, E. P.; Saraiva, C. A. S.; Fonseca, V. de F. C.; Almeida, M. E. V.; Santos, S. G. G. C. dos; Amorim, M. L. C. M.; Rodrigues Neto, P. J. Anatomical and physiological characteristics of dairy cattle to adapt to the tropical environment. Agropecuária Técnica, v.36, p.280-293, 2015.

Rodrigues, V. C.; Silva, I. J. da; Vieira, F. M.; Nascimento, S. T. A correct enthalpy relationship as thermal comfort index for livestock. International Journal of Biometeorology, v.55, p.455459, 2011. https://doi.org/10.1007/s00484-010-0344-y

SAS Institute Inc. SAS ${ }^{\oplus}$ University edition: Installation guide for windows. Cary: SAS Institute Inc., 2016. 24p.

Sun, L. Z.; Auerswald, K.; Wenzel, R.; Schnyder, H. Drinking water intake of grazing steers: The role of environmental factors controlling canopy wetness. Journal of Animal Science, v.92, p.282-291, 2014. https://doi.org/10.2527/jas.2013-6987

Tavares, G. F.; Carnevskis, E. L.; Schiassi, L.; Carlos Filho, R.; Miranda, K. O. da S.; Miranda, J. H. de. Bioclimatic zoning for beef cattle in Brazil with the aid of intelligent systems. Journal of Animal Behaviour and Biometeorology, v.4, p.116-123, 2016. https://doi. org/10.14269/2318-1265/jabb.v4n4p116-123

Thom, E. C. The discomfort index. Weatherwise, v.12, p.57-61, 1959. https://doi.org/10.1080/00431672.1959.9926960

Zanine, A. de M.; Vieira, B. R.; Ferreira, D. de J.; Vieira, A. J. M.; Lana, R. de P.; Cecon, P. R. Ingestive behavior of categories variety of bovines Girolando in pastures of Brachiaria brizantha cv. Marandu. Arquivos de Ciências Veterinárias e Zoologia da UNIPAR, v.11, p.35-40, 2008. 